\title{
Productivity and quality of irrigated organic yellow passion fruits in deep planting in Southeastern Amazon
}

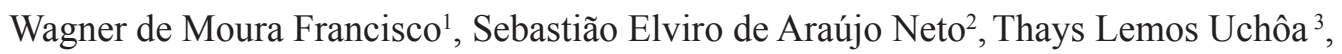 \\ Luís Gustavo de Souza e Souza ${ }^{4}$, Nilciléia Mendes da Silva ${ }^{5}$
}

\begin{abstract}
The aim of this work was to evaluate the effect of irrigation and deep planting of tall yellow passion fruit seedlings in the organic system on fruit quality and productivity. A randomized complete block design with $2 \times 4$ subdivided plots, with 8 treatments and 4 blocks was used, with irrigated and rainfed systems being plots and 4 planting depths $(0.20 \mathrm{~m}, 0.40 \mathrm{~m}, 0.60 \mathrm{~m}$ and 0.80 $\mathrm{m})$ subplots. Seedlings aged 90 days and $2 \mathrm{~m}$ in height were used. Before planting, all stem leaves were removed from seedlings to be buried and to IBA at concentration of $4,000 \mathrm{mg} \mathrm{kg}^{-1}$ was applied. The number of fruits per plant, average fruit mass and total productivity and of $1^{\text {st }}$ and $2^{\text {nd }}$ crops, as well as total soluble solids (TSS), total titratable acidity (TTA), ratio (TSS/TTA), commercial and equatorial diameter classification were estimated. Irrigated planting at depths of $0.20 \mathrm{~m}$ and $0.40 \mathrm{~m}$ was more productive in the first crop, but there was no difference in the total productivity and in the second crop. Neither irrigation nor plant depth altered the chemical quality of fruits and commercial classification.
\end{abstract}

Index terms: Passiflora edulis Sims; Indolbutyric acid (IBA); Tall seedlings; Deep planting.

\section{Produtividade e qualidade dos frutos do maracujazeiro-amarelo orgânico irrigado e em plantio profundo no Sudoeste amazônico}

Corresponding author: wagnerdemoura@outlook.com

Received: December 13, 2019 Accepted: April 29, 2020

Copyright: All the contents of this journal, except where otherwise noted, is licensed under a Creative Commons Attribution License.

\begin{abstract}
Resumo - O objetivo deste trabalho foi avaliar o efeito da irrigação e do plantio profundo de mudas altas de maracujazeiro-amarelo em sistema orgânico sobre a produtividade e a qualidade dos frutos. Foi utilizado o delineamento em blocos casualizados, com parcelas subdivididas $2 \times 4$, com 8 tratamentos e 4 blocos, sendo as parcelas os cultivos irrigado e sequeiro, e as subparcelas as 4 profundidades de plantio $(0,20 \mathrm{~m}, 0,40 \mathrm{~m}, 0,60 \mathrm{~m}$ e $0,80 \mathrm{~m})$. Foram utilizadas mudas altas com 90 dias de idade e $2 \mathrm{~m}$ de altura. Antes do plantio, foram retiradas das mudas todas as folhas da parte do caule a ser enterrado e aplicado AIB, na concentração de $4.000 \mathrm{mg} \mathrm{kg}^{-1}$. Foram avaliados: número de frutos por planta, massa média dos frutos e estimada a produtividade total e da $1^{\mathrm{a}}$ e $2^{\mathrm{a}}$ safras, sólidos solúveis totais (SST), acidez total titulável (ATT), ratio (SST/ATT) e classificação comercial (aparência e diâmetro equatorial). O plantio irrigado e as profundidades de $0,20 \mathrm{~m} \mathrm{e} 0,40 \mathrm{~m}$ foram mais produtivos na $1^{\mathrm{a}}$ safra, porém não houve diferença na produtividade total e na $2^{\mathrm{a}}$ safra. Nem a irrigação, nem a profundidade de plantio alteraram a qualidade química do fruto e sua classificação comercial.

Termos para indexação: Passiflora edulis Sims; Ácido indolbutírico (AIB); Mudas altas; Plantio profundo.
\end{abstract}




\section{Introduction}

Passion fruit is one of the most traded fruits in Brazil, with production of 554,598 tons on 41,090 hectares. In the state of Acre, 925 tons of passion fruit were produced on 110 hectares in 2017, with average yield of 8.5 t.ha $^{-1}$, lower than the national average of 14.1 t.ha $^{-1}$ (IBGE, 2018). The fruit stands out for its characteristic flavor and odor, being used in the manufacture of carbonated drinks, mixed drinks, syrups, jams, dairy products, ice creams, canned foods and pharmaceuticals (SANTOS et al., 2017).

The cultivation of yellow passion fruit is mainly performed in small farms, being one of the main income alternatives. Passion fruit is a technically and economically viable option because it offers fast economic returns and well-distributed revenue in most months of the year. However, low orchard productivity, uneven fruit quality, poor technical assistance and high input costs are problems that need to be addressed to maximize productivity and reduce costs (MELETTI, 2011; NEVES et al., 2010; PIMENTEL et al., 2009).

The edaphoclimatic conditions of the state of Acre are conducive to the cultivation of tropical fruits such as yellow passion fruit. In the region, it can express its greatest productive potential, without showing growth paralysis caused by temperature, which occurs when it is below $16{ }^{\circ} \mathrm{C}$. The biggest problem of the state is water availability during the months from July to September, when rainfall decreases drastically, not providing the necessary amount of water for the plant to have satisfactory flowering, fruiting and growth (CAVICHIOLI et al., 2006; UCHÔA, 2018; ESASHIKA et al., 2018).

The combination of deep planting and the use of taller seedlings (late or large seedlings) with stem rooting induction can anticipate harvest, have lower average cost, favor fruit quality, provide greater initial vegetative biomass, greater resistance to periods of prolonged drought and explore greater soil and water volume, becoming a viable alternative to overcome obstacles of water stress and short periods with low photoperiod (SANTOS et al., 2017).

The aim of this work was to evaluate the effect of irrigation and deep planting of tall yellow passion fruit seedlings in organic system on fruit yield and quality.

\section{Material and methods}

The experiment was carried out at the Serido Ecological Farm, located at the Aquiry Settlement Project, AC 10 road, km 04, José Rui Lino branch, $n^{\circ}$ 1.981, Rio Branco, AC, Brazil, coordinates $09^{\circ} 53$ ' $16^{\prime}$ ' $\mathrm{S}$ and $67^{\circ}$ $49^{\prime} 11^{\prime}$ ' $\mathrm{W}$, and $170 \mathrm{~m}$ a.s.l. The soil of the area has been described as Yellow Acrisol, with sandy loam texture. Soil analysis is shown in Table 1.

Table 1 - Soil analysis of the planting area at Seridó Ecological Farm, Rio Branco-AC, depth of 0-20 cm, 2016

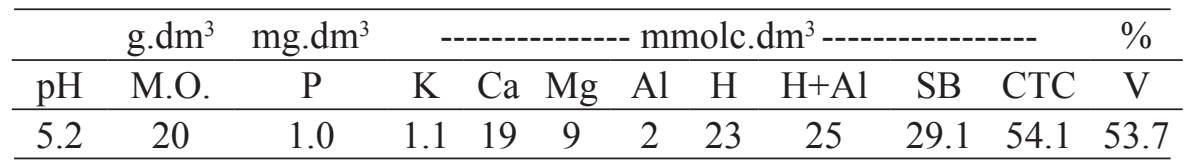

According to the Köppen classification, the climate of the region is characterized as Am, hot and humid. Rainfall and temperature variations were observed during the experiment (Figure 3). The average temperature in the period ranged from $22.44{ }^{\circ} \mathrm{C}$ to $26.71{ }^{\circ} \mathrm{C}$. Cumulative rainfall was $4,368.60 \mathrm{~mm}$, with monthly average of $218.43 \mathrm{~mm}$, with significant rainfall from August 2018 (INMET, 2019).

A randomized complete block design with $2 \times 4$ split plots, with 8 treatments and 4 blocks was used. Plots were irrigated and rainfed systems and subplots the 4 planting depths $(0.20 \mathrm{~m} ; 0.40 \mathrm{~m} ; 0.60 \mathrm{~m}$ and $0.80 \mathrm{~m})$.

For seedling production, seeds of a synthetic yellow passion fruit variety, F3, from the UFAC Germplasm Bank, were used. Seeds were sown in trays on August 2017 and picked for $0.10 \mathrm{~m} \times 0.20 \mathrm{~m}$ plastic bags containing 1.57 L of organic substrate. Seedlings were kept in greenhouse until they reached $2 \mathrm{~m}$ in height, being daily irrigated.
The ten-year-old planting area under grass fallow was used in the previous two years to cultivate yellow passion fruit in an organic system, with manual mowing and cleaning. Planting took place in November 2017, using spacing $3 \mathrm{~m}$ between plants and $2.5 \mathrm{~m}$ between rows, with density of 1,333 plants.ha ${ }^{-1}$.

The stem section to be buried in pits at $0.40 \mathrm{~m}, 0.60$ $\mathrm{m}$ and $0.80 \mathrm{~m}$ in depth was measured, removing leaves, moistening and then applying $4,000 \mathrm{mg} \mathrm{kg-}^{-1}$ of IBA with the aid of brush in the natural incisions of petioles of removed leaves. As there was no stem burial in seedlings planted at depth of $0.20 \mathrm{~m}$, no IBA was applied to them.

Pits were opened with the aid of a motorized manual puncher. Planting fertilization was performed with $12 \mathrm{~L}$ of organic compost, $300 \mathrm{~g}$ thermophosphate and $500 \mathrm{~g}$ of dolomitic limestone per pit. Plants were conducted in vertical shoot positioning with a $2 \mathrm{~m}$ high wire, trapped and stretched by 6 meter spaced posts. 
Irrigation was installed on the planting line, with microsprinkler of flow rate of $67.5 \mathrm{~L} . \mathrm{h}^{-1}$ per plant. Tensiometers installed at $0.15 \mathrm{~m}$ from the plant and at 0.20 $\mathrm{m}$ in depth in the soil were daily analyzed and indicated the beginning of irrigation, which according to Carvalho et al. (2010), occurs when the tensimeter reading is 60 $\mathrm{kPa}$. The gross water depth used was $27.63 \mathrm{~mm}$.

Crowning of spontaneous plants was manually performed by weeding with the help of hoe and mowing of the vegetation between lines with the aid of motorized costal shredder. The control of pests and diseases was based on principles of organic agriculture, using mainly Bordalaise and (1\%) and sulfocalcic $(5 \%)+$ neem oil (1\%) syrup to prevent or reduce the incidence of some fungal agents and Bacillus thurigiensis to combat mainly Dione junojuno and Agraulis vanillae vanillae caterpillars found in the region (REZENDE et al., 2017; UCHOA et al., 2018).

Table 2. Number of defects by category

\begin{tabular}{lccccc}
\hline \multirow{2}{*}{\multicolumn{1}{c}{ Defects }} & \multicolumn{5}{c}{ Categories } \\
\cline { 2 - 6 } & Extra & I & II & III & Organic \\
\hline Immature & $0 \%$ & $2 \%$ & $3 \%$ & $20 \%$ & $0 \%$ \\
Deep damage & $0 \%$ & $1 \%$ & $3 \%$ & $20 \%$ & $0 \%$ \\
Rot & $0 \%$ & $1 \%$ & $3 \%$ & $8 \%$ & $0 \%$ \\
Total severe damages & $0 \%$ & $3 \%$ & $7 \%$ & $100 \%$ & $0 \%$ \\
Total light damages & $5 \%$ & $10 \%$ & $25 \%$ & $100 \%$ & $100 \%$ \\
Overall total & $5 \%$ & $10 \%$ & $25 \%$ & $100 \%$ & $100 \%$ \\
\hline
\end{tabular}

Source: Brazil (2003), with adaptations.

Table 3. Characterization of passion fruit by class or size

\begin{tabular}{cc}
\hline Size & Equatorial diameter $(\mathrm{mm})$ \\
\hline 1 & Equal to or less than 55 \\
2 & Equal to or greater than 55 up to 65 \\
3 & Equal to or greater than 65 up to 75 \\
4 & Equal to or greater than 75 up to 85 \\
5 & Greater than 85 \\
\hline
\end{tabular}

Source: Brazil (2003).

Due to the peculiarities of organic foods, where almost all of them have the presence of some peel deformity, with pulp fully preserved, fitting into categories described in conventional norms is extremely difficult. Thus, based on the conventional classification table, it was proposed that marketable fruits were divided into 2 categories: the percentage of undamaged fruits of each plot was characterized as "extra" and those with only minor defects added to undamaged fruits were classified as "organic", adapting the classification. Fruits with serious defects were considered marketable only for industry.
Harvests were weekly performed in each subplot. Fallen fruits and those with 30\% ripening that were still in the plant were harvested, followed by counting and fresh mass measurement. Manual pollination was carried out between October 2018 and May 2019, counting the number of open flowers. Subsequently, the average number of flowers per plant was calculated.

In this experiment, the number of fruits per plant, average fruit mass and estimated total yield of crop 1 (March /2018 to August /2018) and crop 2 (September /2018 to August /2019) were evaluated. Chemical analyses of total soluble solids, total titratable acidity and TSS/TTA ratio of fruit pulp, classification according to fruit category and class (Table 2 and 3 ) were also performed according to current standard of classification, standardization and identity of yellow passion fruits (BRAZIL, 2003). 


\section{Results and discussion}

The interaction of irrigation and planting depth significantly affected the number of fruits per plant and yield in the first crop (Table 4). The highest number of fruits per plant occurred in irrigated cultivation with 10.06 and 5.54 fruits in plantations with $0.20 \mathrm{~m}$ and 0.40 $\mathrm{m}$ in depth, respectively. The same trend occurred for productivity at depths of $0.20 \mathrm{~m}$ and $0.40 \mathrm{~m}$, with 1.75 t.ha ${ }^{-1}$ and 0.8 t.ha $^{-1}$, respectively, being higher than the others. The low productivity in the off-season is due to the low vegetative biomass of the short production period (5 months) between the end of the juvenile phase and the beginning of the short photoperiod.

Table 4. Number of fruits per plant (NFP), average fruit mass (MMF) and productivity of organic yellow passion fruit in deep planting in irrigated and rainfed systems in the municipality of Rio Branco-AC, from March 2018 to August $2018\left(1^{\text {st }} \mathrm{crop}\right)$

\begin{tabular}{ccccccc}
\hline Depth $(\mathrm{m})$ & \multicolumn{2}{c}{ NFP (und) } & \multicolumn{2}{c}{ MMF $(\mathrm{g}){ }^{\text {ns }}$} & \multicolumn{2}{c}{ Productivity $\left(\right.$ t.ha $\left.{ }^{-1}\right)$} \\
\hline & Irrigated & Rainfed & Irrigated & Rainfed & Irrigated & Rainfed \\
\hline 0.20 & $10.06 \mathrm{Aa}$ & $04.25 \mathrm{Ab}$ & 130.54 & 117.88 & $1.75 \mathrm{Aa}$ & $0.66 \mathrm{Ab}$ \\
0.40 & $05.54 \mathrm{ABa}$ & $06.00 \mathrm{Aa}$ & 110.06 & 115.87 & $0.79 \mathrm{ABa}$ & $1.03 \mathrm{Aa}$ \\
0.60 & $01.75 \mathrm{Bb}$ & $05.64 \mathrm{Aa}$ & 117.69 & 132.37 & $0.26 \mathrm{Ba}$ & $1.12 \mathrm{Aa}$ \\
0.80 & $03.06 \mathrm{Ba}$ & $02.25 \mathrm{Aa}$ & 113.63 & 113.61 & $0.46 \mathrm{Ba}$ & $0.36 \mathrm{Aa}$ \\
\hline $\mathrm{CV}(\%)$ & \multicolumn{3}{c}{29.64} & \multicolumn{3}{c}{15.59} \\
\hline
\end{tabular}

Means followed by equal lowercase letters in the row and uppercase letters in the column do not differ from each other ( $p>0.05)$.

ns - No significant difference ( $\mathrm{p}>0.05)$.

Some soaking points were observed in the experimental area due to the characteristics of moderate soil drainage and rainfall in 2017 and 2018 being 33.49\% higher than in 2016 (Figure 1), which may mask some irrigation effect (INMET, 2019). Deep planting cultivation may have caused stress on plants with higher energy expenditure for stem rooting due to oxygen deficiency in the deepest layers and high rainfall at the time, with yellow passion fruit being sensitive to soil soaking (SANTOS et al., 2017).

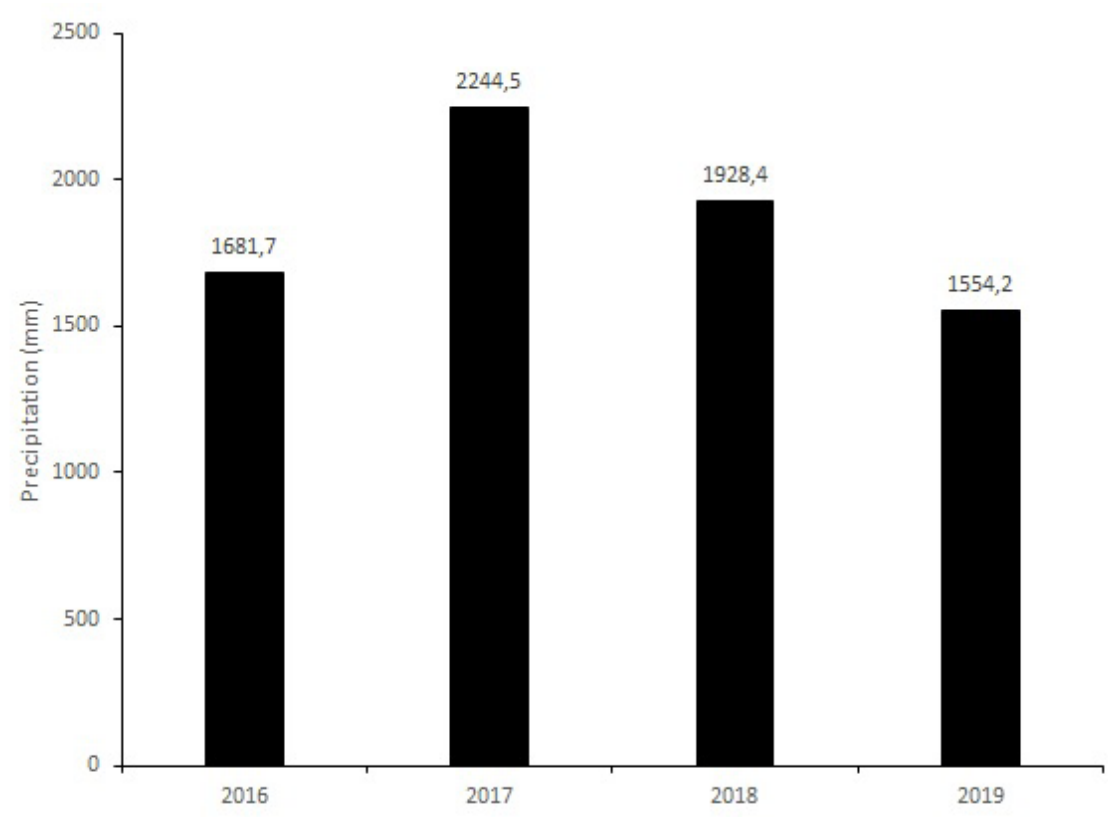

Figure 1 - Annual rainfall (mm) in the municipality of Rio Branco in 2016-2019 (Jan/Aug) 
In soaked soil, water fills pores and blocks $\mathrm{O}_{2}$ diffusion, keeping only a few centimeters near the oxygenated surface. Combined with temperatures above $20{ }^{\circ} \mathrm{C}$, as in the region of the experiment, oxygen uptake by roots and soil microbiota can deplete it in less than 24 hours (TAIZ; ZEIGER, 2013). As a result, plants at the lowest depths $(0.20 \mathrm{~m}$ and $0.40 \mathrm{~m})$ had higher biomass and higher number of fruits and yield in the first production months (Table 5).

Table 5. Canopy volume per plant $\left(\mathrm{m}^{3}\right)$ of organic yellow passion fruit in deep planting in irrigated and rainfed systems in the city of Rio Branco-AC

\begin{tabular}{cccccc}
\hline \multirow{2}{*}{ Form of cultivation } & \multicolumn{5}{c}{ Depths (m) } \\
\cline { 2 - 5 } & 0.20 & 0.40 & 0.60 & 0.80 & \\
\hline Irrigated & 2.76 & 2.33 & 1.88 & 1.99 & 2.24 \\
Rainfed & 2.50 & 2.50 & 2.37 & 1.73 & 2.28 \\
\hline Mean & 2.63 & 2.41 & 2.13 & 1.86 & \\
\hline
\end{tabular}

Comparing irrigated and rainfed systems in planting with $0.20 \mathrm{~m}$ in depth, irrigation provided plants with higher average number of fruits and yield of $136.71 \%$ and $167.16 \%$, respectively. However, at depth of 0.60 $\mathrm{m}$, the rainfed system yielded $222.29 \%$ more fruits per plant and $324.63 \%$ higher yield compared to the irrigated system. This is possibly due to the better use of water by roots and less problems with oxygen deficiency in the soil, which may have influenced the lower results obtained in planting at $0.80 \mathrm{~m}$ in depth.
In the second crop, there was difference only for the average fruit mass (MMF) (Table 6). The depth of $0.80 \mathrm{~m}$ provided the lowest average mass (113.46 g.fruit $\left.{ }^{-1}\right)$, probably due to the lower availability of $\mathrm{O}_{2}$ and nutrients in deeper soil layers, forming smaller canopy volume, reducing its photosynthetic capacity. There may be a decrease in the average fruit mass in the second crop, when production peak is usually observed due to the greater distribution of photo assimilates by plants, a condition not observed in this experiment, because fruit mass was similar to that of the first crop, as in the work of Reis et al. (2018).

Table 6. Number of fruits per plant (NFP), average fruit mass (MMF) and productivity of organic yellow passion fruit in deep planting in irrigated and rainfed systems in the municipality of Rio Branco-AC, from September 2018 to August 2019 ( $2^{\text {nd }}$ crop).

\begin{tabular}{|c|c|c|c|c|c|c|}
\hline \multirow[t]{2}{*}{ Depth (m) } & \multicolumn{2}{|c|}{ NFP (und) ${ }^{\mathrm{ns}}$} & \multicolumn{2}{|c|}{ MMF (g) } & \multicolumn{2}{|c|}{ Productivity $\left(\mathrm{t} \cdot \mathrm{ha}^{-1}\right)^{\mathrm{ns}}$} \\
\hline & Irrigated & Rainfed & Irrigated & Rainfed & Irrigated & Rainfed \\
\hline 0.20 & 101.15 & 096.94 & $112.72 \mathrm{~A}$ & $123.15 \mathrm{AB}$ & 15.09 & 16.18 \\
\hline 0.40 & 073.56 & 097.06 & $118.25 \mathrm{~A}$ & $118.72 \mathrm{AB}$ & 11.57 & 15.14 \\
\hline 0.60 & 057.81 & 082.06 & $120.87 \mathrm{~A}$ & $128.26 \mathrm{~A}$ & 09.73 & 15.59 \\
\hline 0.80 & 087.75 & 080.16 & $113.69 \mathrm{~A}$ & $113.46 \mathrm{~B}$ & 13.08 & 12.17 \\
\hline CV $(\%)$ & \multicolumn{2}{|c|}{37.23} & \multicolumn{2}{|c|}{07.46} & \multicolumn{2}{|c|}{41.59} \\
\hline
\end{tabular}

Means followed by equal lowercase letters in the row and uppercase letters in the column do not differ from each other ( $\mathrm{p}>0.05$ ). ns - No significant difference $(\mathrm{p}>0.05)$. 
There was no difference between number of fruit per plant and yield in second passion fruit crop (Table 6), indicating that the application of IBA before planting may have provided higher rooting rate, increasing the absorption of water and nutrients, thus helping to equate the production of passion fruits planted in higher depth with those in lower depth, overcoming obstacles of the $1^{\text {st }}$ crop (TAIZ; ZEIGER, 2013). In addition, there was low flowering rate between mid July and August 2018, which is related to the shorter photoperiod and low water availability in the region (CAVIOCHIOLI et al., 2006).
Considering total production, there was no difference among treatments. Exogenous IBA application and rainfall in the period may have contributed to the equated yields in irrigated and rainfed systems (Table 7). NFP ranged from 59.33 to 110.83 fruits, similar to that obtained by Hafle et al. (2009), working with pruning of the yellow passion fruit productive branches $(46.37$ to 94.25 NFP).

Table 7. Number of fruits per plant (NFP), average fruit mass (MMF) and total yield of organic yellow passion fruit in deep planting in irrigated and rainfed systems in Rio Branco-AC.

\begin{tabular}{ccccccc}
\hline Depth $(\mathrm{m})$ & \multicolumn{2}{c}{ NFP (und) ${ }^{\mathrm{ns}}$} & \multicolumn{2}{c}{ MMF $(\mathrm{g})^{\mathrm{ns}}$} & \multicolumn{2}{c}{ Productivity $\left(\mathrm{t} . \mathrm{ha}^{-1}\right)^{\mathrm{ns}}$} \\
\hline & Irrigated & Rainfed & Irrigated & Rainfed & Irrigated & Rainfed \\
0.20 & 110.83 & 101.06 & 121.59 & 120.53 & 16.84 & 16.83 \\
0.40 & 78.48 & 102.56 & 114.08 & 123.45 & 12.36 & 16.16 \\
0.60 & 59.33 & 93.78 & 124.38 & 134.60 & 10.00 & 16.72 \\
0.80 & 90.25 & 81.79 & 113.67 & 113.56 & 13.55 & 12.53 \\
\hline $\mathrm{CV}(\%)$ & \multicolumn{2}{c}{37.77} & \multicolumn{2}{c}{11.94} & \multicolumn{2}{c}{41.66} \\
\hline
\end{tabular}

Means followed by equal lowercase letters in the row and uppercase letters in the column do not differ from each other ( $\mathrm{p}>0.05$ ). ${ }^{\text {ns }}-$ No significant difference $(\mathrm{p}>0.05)$.

The total average fruit mass ranged from 113.67 $\mathrm{g}$ to $134.60 \mathrm{~g}$. Values were similar to those found by Rezende et al. (2017), working with grafting to recover the yellow passion fruit stem, where MMF ranged from $117.7 \mathrm{~g}$ to $126.5 \mathrm{~g}$.

The cultivar used and the low input levels used in organic agriculture, even without the addition of high nitrogen doses, can affect fruit mass. Pereira et al. (2018) characterized fruits of different passion fruit species and reported that FB 200 hybrid in conventional planting reached average fruit mass of $310 \mathrm{~g}$.

The highest total yield obtained was 16.84 t.ha $^{-1}$, higher than the national and state average of 14.1 t.ha $^{-1}$ and 8.5 t.ha $^{-1}$, respectively (IBGE, 2018). Although yellow passion fruit has potential to produce up to $68.8 \mathrm{t}^{\mathrm{ha}} \mathrm{ha}^{-1}$, this yield is achieved only with high input levels, pollination and protected environment (CARVALHO et al., 2010). In organic cultivation, with low input use, productivity is lower, ranging from 4 t.ha ${ }^{-1}$ (ARAÚJO NETO et al., 2009) to 21 t.ha $^{-1}$ (ARAÚJO NETO et al., 2014).
Similar results were obtained by Krause et al. (2012), working with fruit productivity and quality with and without artificial pollination, producing 16.41 th.ha ${ }^{-1}$. Uchôa et al. (2018) tested different mulch in organic management levels and obtained 5.18 t.ha $^{-1}$ in the first crop with longer production period (11 months).

Several factors can interfere passion fruit productivity and quality, especially temperature, precipitation, relative humidity, light, cultural management and variety (LIMA; BORGES, 2002). The variation in the number of fruits per plant, average fruit mass, yield and flowering (number of flowers per plant per day) in relation to climatological data can be observed in Figure 2 and 3.

There was no difference among treatments for total soluble solids (TSS), total titratable acidity (TTA) and TTA/TSS ratio. TSS ranged from $17.29^{\circ}$ brix to 17.94 ${ }^{\circ}$ Brix, the TTA from $3.65 \%$ to $4.08 \%$ and ratio from 4.27 to 4.90 (Table 8). 


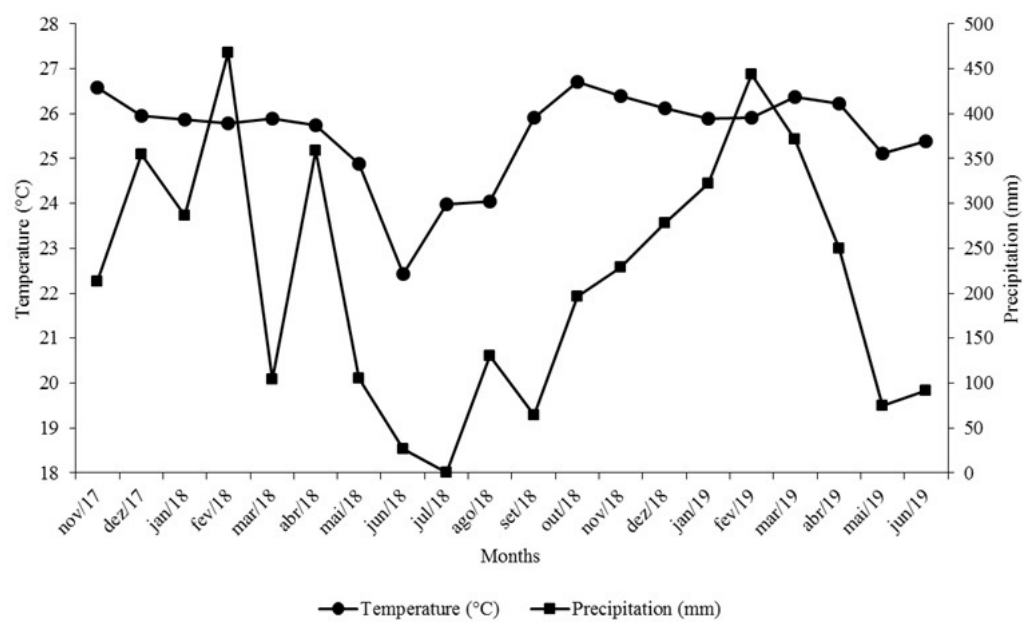

Figure 2. Average temperature and precipitation in Rio Branco-AC during the experimental period (November 2017 to June 2019).
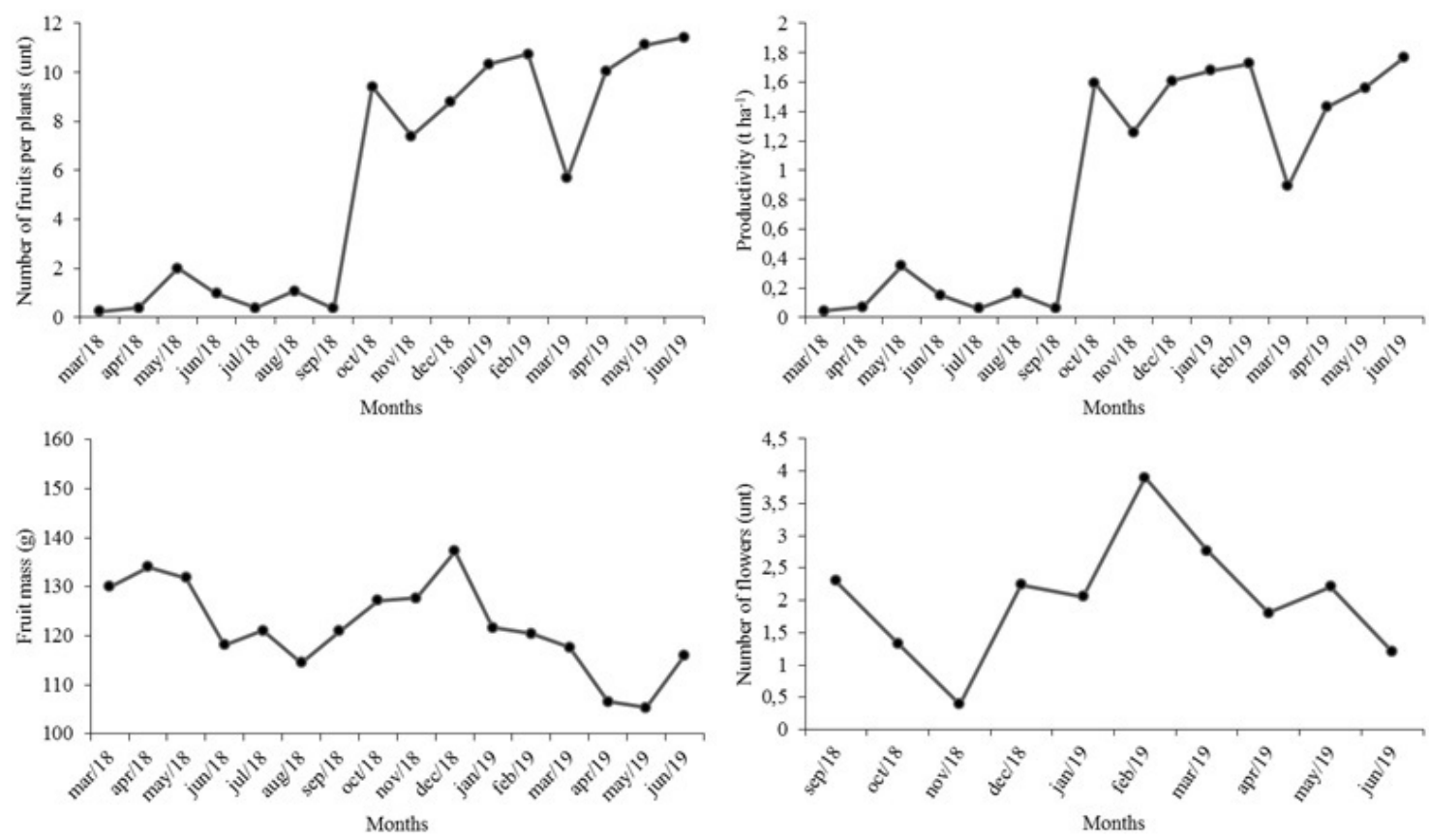

Figure 3. Number of fruits per plant (NFP), average fruit mass (MMF), productivity (PROD) and number of flowers per plant (FPP) during the period of organic yellow passion fruit production in deep planting in irrigated and rainfed systems in the municipality of Rio Branco-AC.

Table 8. Total soluble solids (TSS), total titratable acidity (TTA) and TSS/TTA ratio of organic yellow passion fruit fruits in deep planting in irrigated and rainfed systems in Rio Branco-AC

\begin{tabular}{ccccccc}
\hline Depth $(\mathrm{m})$ & \multicolumn{2}{c}{ TSS $^{\circ}{ }^{\circ}$ brix $)^{\text {ns }}$} & \multicolumn{2}{c}{ TTA $(\%){ }^{\text {ns }}$} & \multicolumn{2}{c}{ Ratio $^{\text {ns }}$} \\
\hline & Irrigated & Rainfed & Irrigated & Rainfed & Irrigated & Rainfed \\
\hline 0.20 & 17.79 & 17.29 & 3.92 & 3.94 & 4.54 & 4.41 \\
0.40 & 17.70 & 17.39 & 3.82 & 3.90 & 4.66 & 4.50 \\
0.60 & 17.54 & 17.94 & 3.65 & 3.93 & 4.90 & 4.58 \\
0.80 & 17.33 & 17.45 & 3.75 & 4.08 & 4.65 & 4.27 \\
\hline CV $(\%)$ & \multicolumn{2}{c}{04.55} & \multicolumn{2}{c}{08.51} & \multicolumn{2}{c}{09.14} \\
\hline
\end{tabular}

Means followed by equal lowercase letters in the row and uppercase letters in the column do not differ from each other ( $p>0.05$ ). ${ }^{\text {ns }}-$ No significant difference $(\mathrm{p}>0.05)$. 
Soluble solids are parameters used as reference for the quality of fruits destined for pulp industrialization and must have contents higher than $11^{\circ}$ Brix (BRAZIL, 2018). According to Figueiredo et al. (2015), the fresh fruit market prefers fruits with higher TSS and lower TTA.

The average fruit acidity was $3.87 \%$, similar to value found by Santos et al. (2017) working with the quality of yellow passion fruit fruits from seedlings of various ages, with average of $3.82 \%$. TTA varies mainly according to the ripening stage and harvesting season, and treatments are not significant to cause chemical changes in fruits. Uchôa et al. (2018) worked with the performance of yellow passion fruits under mulch also did not obtain significant difference for TSS, TTA and ratio contents, as Rezende et al. (2017), evaluating grafting for the recovery of yellow passion fruit stem in organic system.
According to Santos et al. (2017), ratio is an important feature to evaluate the quality of passion fruits because it indicates its palatability and flavor. TSS/TTA values between 3.4 and 4.5 demonstrate that the fruit can be destined for both fresh consumption and industry, as fruits produced in this experiment, whose average was 4.56 .

There was no statistical difference among treatments regarding fruit classification. On average, $21 \%$ of fruits produced had no damage and $70 \%$ had slight damage (Table 9), still occurring in the field, indicating good receptivity in fresh fruit sales, where consumers prefer fruits with good external appearance (PACHECO et al., 2016).

Table 9. Classification of fruits in relation to the appearance of organic yellow passion fruits in deep planting in irrigated and rainfed systems in the municipality of Rio Branco-AC

\begin{tabular}{ccccc}
\hline Depth $(\mathrm{m})$ & \multicolumn{2}{c}{ Organic $(\%)^{\mathrm{ns}}$} & \multicolumn{2}{c}{ Extra $(\%)^{\mathrm{ns}}$} \\
\hline & Irrigated & Rainfed & Irrigated & Rainfed \\
\hline 0.20 & 89.17 & 90.83 & 22.50 & 14.17 \\
0.40 & 90.83 & 92.50 & 30.83 & 26.67 \\
0.60 & 90.00 & 85.00 & 14.17 & 20.83 \\
0.80 & 90.01 & 85.83 & 16.67 & 23.33 \\
\hline CV (\%) & \multicolumn{3}{c}{08.12} & \multicolumn{2}{c}{59.27} \\
\hline
\end{tabular}

Means followed by equal lowercase letters in the row and uppercase letters in the column do not differ from each other ( $p>0.05$ ). ${ }^{\text {ns }}-$ No significant difference $(\mathrm{p}>0.05)$.

Chaboussou (1987) suggests that nutritionally unbalanced plants, mainly due to the excessive use of highly soluble mineral fertilizers, tend to have metabolic problems, as in proteosynthesis and proteolysis processes, increasing the amount of soluble amino acids, sugars and minerals, making fruits and leaves more susceptible to pests and diseases, influencing the increase in the number of defects, harming the appearance of fruits.

Even following crop management according to principles of organic farming, without the use of highly soluble fertilizers and conventional pesticides, there was high incidence of slight defects, probably due to some insects and fungi, but all below the level of economic damage.
Fruit diameter was affected by the interaction between irrigation and planting depth in classes D2 (55 $\mathrm{mm}$ to $65 \mathrm{~mm}$ ) and D3 (65 mm to $75 \mathrm{~mm})$, the most representative in this research, totaling about $75 \%$ of fruits (Table 10). Planting at $0.60 \mathrm{~m}$ in the rainfed system had the lowest percentage of class D2 fruits, statistically equal to depth of $0.40 \mathrm{~m}$. Irrigation provided $77.78 \%$ more class D2 fruits compared to rainfed. 
Table 10. Classification of fruits in relation to the diameter of organic yellow passion fruit in deep planting in irrigated and rainfed systems in the municipality of Rio Branco-AC

\begin{tabular}{|c|c|c|c|c|}
\hline \multirow[t]{2}{*}{ Depth (m) } & \multicolumn{2}{|c|}{$\mathrm{D} 1(\%)^{\mathrm{ns}}$} & \multicolumn{2}{|c|}{ D2 (\%) } \\
\hline & Irrigated & Rainfed & Irrigated & Rainfed \\
\hline 0.20 & 10.83 & 07.52 & $40.83 \mathrm{Aa}$ & $41.67 \mathrm{Aa}$ \\
\hline 0.40 & 10.00 & 15.83 & $39.17 \mathrm{Aa}$ & $29.17 \mathrm{ABa}$ \\
\hline 0.60 & 14.17 & 10.00 & $40.00 \mathrm{Aa}$ & $22.50 \mathrm{Bb}$ \\
\hline 0.80 & 15.02 & 10.83 & $34.17 \mathrm{Aa}$ & $45.00 \mathrm{Aa}$ \\
\hline CV (\%) & \multicolumn{2}{|c|}{47.57} & \multicolumn{2}{|c|}{25.45} \\
\hline Depth (m) & \multicolumn{2}{|c|}{ D3 (\%) } & \multicolumn{2}{|c|}{$\mathrm{D} 4(\%)^{\mathrm{ns}}$} \\
\hline 0.20 & $37.50 \mathrm{Aa}$ & $35.00 \mathrm{ABa}$ & 10.00 & 15.00 \\
\hline 0.40 & $30.83 \mathrm{Aa}$ & $38.33 \mathrm{ABa}$ & 15.83 & 14.17 \\
\hline 0.60 & $31.67 \mathrm{Ab}$ & $43.33 \mathrm{Aa}$ & 14.17 & 20.02 \\
\hline 0.80 & $32.50 \mathrm{Aa}$ & $27.50 \mathrm{Ba}$ & 16.67 & 16.67 \\
\hline CV (\%) & \multicolumn{2}{|c|}{21.21} & \multicolumn{2}{|c|}{46.34} \\
\hline
\end{tabular}

Means followed by equal lowercase letters in the row and uppercase letters in the column do not differ from each other ( $\mathrm{p}>0.05$ ).ns - No significant difference $(p>0.05)$.

For class D3 fruits, the lowest percentage of fruits was obtained in planting with $0.80 \mathrm{~m}$ in depth in the rainfed system. In the $0.60 \mathrm{~m}$ planting, the absence of irrigation produced $36.81 \%$ more D3 fruits compared with presence of irrigation. The smaller canopy volumes in the $0.80 \mathrm{~m}$ depth planting may have interfered with the lower photosynthesis production, contributing to the presence of smaller fruits (CAVICHIOLI et al., 2006).

The overall average fruit diameter was $66 \mathrm{~cm}$. According to Krause et al. (2012) and Pereira et al. (2018), genetic and environmental factors and the lack of artificial pollination influence yellow passion fruit production and productivity.

\section{Conclusions}

Yellow passion fruit trees produce fewer fruits per plant in the $1^{\text {st }}$ crop and lower average fruit mass in the $2^{\text {nd }}$ crop at higher planting depths.

Irrigation increases productivity in shallow planting in the $1^{\text {st }}$ yellow passion fruit crop.

The deep yellow passion fruit planting and the use of irrigation did not change the chemical quality of fruits or their classification.

\section{References}

ARAÚJO NETO, S.E. de; CAMPOS, P.A.; TAVELLA, L.B.; SOLINO, A.J. da S.; SILVA, I.F. da. Organic polyculture of passion fruit, pineapple, corn and cassava: the influence of green manure and distance between espaliers. Ciência e Agrotecnologia, Lavras, v.38, n.3, p.247-255, 2014.

ARAÚJO NETO, S.E. de; SOUZA, S.R. de; SALDANHA, C.S.; FONTINELE, Y. da R.; NEGREIROS, J.R. da S.; MENDES, R.; AZEVEDO, J.M.A. de; OLIVEIRA, E.B. de L. Produtividade e vigor do maracujazeiro-amarelo plantado em covas e plantio direto sob manejo orgânico. Ciência Rural, Santa Maria, v.39, n.3, p.678-683, 2009.

BRASIL. Ministério da Integração Nacional. Programa brasileiro para a melhoria dos padrões comerciais e embalagens de horticultura. Brasília, 2003. Disponível em: http//:www.integracao.gov.br. Acesso em: 23 maio 2019. 
BRASIL. Ministério da Agricultura e do Abastecimento. Regulamento Técnico geral para fixação dos padrões de identidade e qualidade para polpa de fruta. Instrução normativa $n^{\circ} 37$, de 1 de outubro de 2018. Diário Oficial da República Federativa do Brasil, Brasília, DF, 8 out. 2018. Disponível em: www.agricultura.gov.br. Acesso em: 03 out. 2019.

CARVALHO, J. de A.; KOETZ, M.; SOUSA, A.M.G. de; SOUZA, K.J. de. Desenvolvimento e produtividade do maracujazeiro-amarelo irrigado sob diferentes lâminas de irrigação em ambiente protegido e natural. Engenharia Agrícola, Jaboticabal, v.30, n.5, p.862-874, 2010.

CAVICHIOLI, J.C.; RUGGIERO, C.; VOLPE, C.A.; PAULO, E.M.; FAGUNDES, J.L.; KASAI, F.S. Florescimento e frutificação do maracujazeiroamarelo submetido a iluminação artificial, irrigação e sombreamento. Revista Brasileira de Fruticultura, Jaboticabal, v.28, n.1, p.92-96, 2006.

CHABOUSSOU, F. Plantas doentes pelo uso de agrotóxicos: a teoria da trofobiose. Porto Alegre: L\&PM, 1987. $256 \mathrm{p}$.

ESASHIKA, D.A. de S.; FALEIRO, F.G.; JUNQUEIRA, N.T.V. Phenology of the production of flowers and fruits of wild and hybrid species of the genus Passiflora. Revista Brasileira de Fruticultura, Jaboticabal, v.40, n.2, e-188, 2018.

FIGUEIREDO, F.R.A.; HAFLE, O.M.; RODRIGUES, M.H.B.S.; PEREIRA JÚNIOR, E.B.; DELFINO, F.I. Produtividade e qualidade dos frutos do maracujazeiroamarelo sob diferentes formas de condução das plantas. Agropecuária Científica no Semiárido, Campina Grande, v.11, n.04, p.23-32, 2015.

HAFLE, O.M.; RAMOS, J. d.; LIMA, L.C. de O.; FERREIRA, E.A.; MELO, P.C. de. Produtividade e qualidade de frutos do maracujazeiro-amarelo submetido à poda de ramos produtivos. Revista Brasileira de Fruticultura, Jaboticabal, v.31, n.3, p.763-770, 2009.

IBGE - Instituto Brasileiro de Geografia e Estatística. Produção agrícola municipal: culturas temporárias e permanentes. Rio de Janeiro, 2018. Disponível em: http://www.sidra.ibge.gov.br/ bda/tabela/ listabl. asp? $\mathrm{c}=1613 \& \mathrm{z}=\mathrm{p} \& \mathrm{o}=28$. Acesso em: 11 ago. 2019.
INMET- Instituto Nacional de Meteorologia. Banco de dados meteorológicos para ensino e pesquisa. Brasília, 2019. Disponível em: http://www.inmet.gov.br/portal/ index.php? r=bdmep/bdmep. Acesso em: 11 jun. 2019.

KRAUSE, W.; NEVES, L.G.; VIANA, A.P.; ARAÚJO, C.A.T.; FALEIRO, F.G. Produtividade e qualidade de frutos de cultivares de maracujazeiro amarelo com ou sem polinização artificial. Pesquisa Agropecuária Brasileira, Brasília, DF, v.47, n.12, p.1737-1742, 2012.

LIMA, A.A.; BORGES, A.L. Solo e clima. In: LIMA, A.A. Maracujá produção: aspectos técnicos. Brasília: EMBRAPA, 2002. p.25-28.

MELETTI, L.M.M. Avanços na cultura do maracujá no Brasil. Revista Brasileira de Fruticultura, Jaboticabal, v.33, nesp., p.83-91, 2011.

NEVES, L.G.; BRUCKNER, C.H.; CRUZ, C. d.; BARELLI, M.A.A. Avaliação da repetibilidade no melhoramento de famílias de maracujazeiro. Revista Ceres, Viçosa, MG, v.57, n.4, p.480-485, 2010.

PACHECO, A.L.V.; PAGLIARINI, M.F.; VIEIRA, G.; FREITAS, G.B. de. Influência da adubação orgânica sobre a classificação e aparência dos frutos de maracujazeiroamarelo. Revista Brasileira de Agropecuária Sustentável, Viçosa, MG, v.6, n.2, p.43-50, 2016.

PEREIRA, L. d.; VALLE, K. d. do; SOUZA, L.K.F. de; ASSUNÇÃO, H.F. da; BOLINA, C. de C.; REIS, E.F. dos; SALAZAR, A.H.; SILVA, F.P. da. Caracterização de frutos de diferentes espécies de maracujazeiro. Revista Brasileira de Agropecuária Sustentável, Viçosa, MG, v.08, n.2, p.21-28, 2018.

PIMENTEL, L.D.; SANTOS, C.E.M. dos; FERREIRA, A.C.C.; MARTINS, A.A.; WAGNER JÚNIOR, A.; BRUCKNER, C.H. Custo de produção e rentabilidade do maracujazeiro no mercado agroindustrial da Zona da Mata Mineira. Revista Brasileira de Fruticultura, Jaboticabal, v.31, n.2, p.397-407, 2009.

REIS, L.C.; FORESTI, A.C.; RODRIGUES, E.T. desempenho de cultivares de maracujá (Passiflora edulis f.flavicarpa) no sistema de produção orgânico. Revista de la Facultad de Agronomia, La Plata, v.117, n.02, p.253-260, 2018. 
REZENDE, M.I.F.L.; ARAÚJO NETO, S.E.; LUSTOSA, C.; HAFLE, O.M.; PENHA PINTO, G.P. Grafting for the recovery of yellow passion fruit stem in organic system. Revista Brasileira de Fruticultura, Jaboticabal, v.39, n.1, p.e-745, 2017.

SANTOS, V.A. dos; RAMOS, J. d.; LAREDO, R.R.; SILVA, F.O. dos R.; CHAGAS, E.A.; PASQUAL, M. Produção e qualidade de frutos de maracujazeiro-amarelo provenientes do cultivo com mudas em diferentes idades. Revista de Ciências Agroveterinárias, Lages, v.16, n.1, p.33-40, 2017.
TAIZ, L.; ZEIGER, E. Fisiologia vegetal. Porto Alegre: Artmed, 2013. 918 p.

UCHOA, T.L.; ARAUJO NETO, S.E. de.; SELHORST, P.O.; RODRIGUES, M.J. da S.; GALVÃO, R. de O. Yellow passionfruit performance in organic crop under mulch. Revista Brasileira de Fruticultura, Jaboticabal, v.40, n.2, p.e-212, 2018. 